\title{
Myth and Epic
}

\author{
Harold Toliver \\ University of California, Irvine, USA \\ Email: hetolive@uci.edu
}

Received November 19 $9^{\text {th }}, 2013$; revised December 21 $1^{\text {st }}, 2013$; accepted January $6^{\text {th }}, 2014$

\begin{abstract}
Copyright (C) 2014 Harold Toliver. This is an open access article distributed under the Creative Commons Attribution License, which permits unrestricted use, distribution, and reproduction in any medium, provided the original work is properly cited. In accordance of the Creative Commons Attribution License all Copyrights (c) 2014 are reserved for SCIRP and the owner of the intellectual property Harold Toliver. All Copyright (C) 2014 are guarded by law and by SCIRP as a guardian.
\end{abstract}

\begin{abstract}
Anthrologists and literary critics tend to read even sacred ancient literature in the manner of Homer's and Virgil's epics, that is, as fiction with historical elements. They don't, however, always follow up with the implications of that. Mesopotamian myths and epics are similar to Greek and Roman ones in that regard. The pertinent questions are who believed what and what effect literal belief in myths had on given social orders. One answer in the Hebraic tradition is typical of other traditions, namely that calls for reform at home and for campaigns against enemies abroad rely heavily on the presumed historicity of the texts. For the Israelites, that means the unquestioned validity of covenants struck between legendary patriarchs and Yahweh, at least within the Yahweh cult itself. The hybrid forms of Dante, Milton, and others in the Christian European tradition draw on both well-traveled epic conventions and the veracity of biblical traditions, as Milton does in turning a Homeric invocation of the muse into an appeal to the Holy Spirit. Much as Milton, too, is now read as a poet rather than an inspired seer, so probably were earlier authors who claimed direct personal revelations. If that was in fact the case, it would have weakened moral teachings less than cult recruitment and the call for military campaigns against foreign powers. Whereas legal and ethical matters have much to recommend them independently of their origin, waging war on religious grounds requires strong convictions.
\end{abstract}

Keywords: Myth; Epic; Yahweh; Oracle; Tradition; Milton; Genre; Mesopotamia; Israel; Imperialism; Belatedness; Rhetoric; Belief; Homer; Satan

\section{What's in a Name}

Merely name a character in an epic Zeus or Venus and the nature of the narrative changes drastically. Thus when Milton introduces the Father/Son dialogues of Paradise Lost III, we learn ahead of time how Adam and Eve will be judged and how satanic posturing will be dealt with. That isn't a story-telling device for Milton. He clearly believes that man's first disobedience has in fact brought ruin to mankind and altered the original topography and climate of the planet. For modern readers, belief in the historical veracity is usually limited to texts which are still considered to be inspired. The parent texts behind many of the western and near eastern traditions are those collected in the Hebrew anthology, where Yahweh defines enemies, sets battle plans, and sees to the discomfiture of enemies. The covenants he strikes with Abraham and Moses set the terms of over a thousand years of presumed national history. Belief in that historicity underlies the laws and ordinances of Leviticus and Deuteronomy and eventually Christianity and Islam.

Myths in Hesiod's Theogony (2004) and the epics of Homer, Virgil, Lucan, and Statius are less likely to assert judgments openly and make no pretense to the law-making not only of Yahweh but of the Mesopotamian Anunnaki. In openly fictional myth and epic, moral questions and character are more shaded and ambiguous than they are in the oracles. Achilles and
Hector are complex characters. With his brutal slaying of Turnus, Aeneas presents a somewhat clouded and tarnished heritage to Augustus and current Roman ambitions for the expansion of the empire. That is decidedly not the case with the Hammurabi Code, oracular sermons, and the laws and ordinances of Leviticus and Deuteronomy.

In any age or any culture, one obvious benefit of simulated history reinforced by divine connections is that the circle of believers - the cult and perhaps the nation-occupies moral high ground. Recipients of revelations have advantages in raising armies, as they did not only in the soothsayer-validated expeditions of Mesopotamia and the wars of Yahweh but in the Crusades and still do in terrorist cells. Thus joined to the warrior elements of epic, the advantages carry into administrative hierarchies and fields of battle, increasing the harangue potential and transforming the poet into the prophet.

As I indicated, such texts look altogether different outside the times and regions, all the more so in the light of the natural history of the past several centuries. Why belief is regional and communal is a question for brain studies like those of Thomas Gilovich (1991) and Michael Shermer (2011). I'll leave that aspect of belief with merely the observation that for genetic reasons people are vulnerable to knowing "what isn't so", in Gilovich's phrase. A Hindu reading Paradise Lost has less difficulty taking it as an epic style fiction than at least some 17th century Christians did. Reconstructing effects on readers 
long after the fact is difficult, but what a text implies about its expectations for the rank and file is often reasonably clear where we know enough about the context. Epics and oracular sermons have named authors and hence are more available for Sitz im leben (contextual) studies than mythology normally is. Myths too once had social settings, however. We may not know what those were in any detail, but the author's address to his audience tells us a good deal. What people are assumed to be thinking guides the author's admonition of them and extracts his claim to authenticity.

Whether biblical or another other kind of sacred literature from Persia, Mesopotamia, Egypt, or Rome, any highly valued heritage has an indoctrination side to it. That should go without argument: it wasn't the divine council that wrote the Hammurabi Code but Hammurabi and his administration. Only regionally were the Anunnaki thought to be represented in the Tablet of Destinies that granted extraordinary power to those who held it. Ruling authority was no less tangible at the administrative level for that. From gods it descended to emperors and continued on down into the bureaucracy.

In the heroic literature of Sumeria, the first of its kind recorded in writing, some of the deities in question probably grew initially out of personifications of natural forces, but in taking on lives and character they ceased to be restricted to raising storms or making the sun shine. In establishing surrogates in kings, Utu, the sun (later Shamash), assumed social relevance well beyond anything directly related to the sun. That pattern of broadening top-down agency held from the first known examples all the way through European divine right monarchs. None of the validity claims retains any credibility in the light of natural history, though similar ones still crop up under the influence of sects adhering to ancient texts. Over a period of several millennia, myths that applied to civil affairs appear to have been nearly as widespread as civilizations.

Where an urban center was involved, tensions between center and perimeter complicated the chain of command. Adding required conformity in belief to tribute owed to the ruling center doubled the grounds for foment. Much of the presumed history of ancient Israel is devoted to apostasy and dissent outside Jerusalem, the main cause of the divine wrath the prophets expect to be visited on offending parties.

Outside of backward regions, few nationalist campaigns are any longer presented as holy wars, but as I suggested the myth of divine causes and even mandates hasn't completely disappeared. Mein Kampf, to take an infamous 20th century example, combined harangue with prophet-like visions of a cleansed world. Joseph Goebbels, Otto Dietrich, and Adolf Hitler considered the extermination of the Jews the work of the Lord, or said they did. For the most part we can skip what ministries of propaganda have produced as of negligible literary value, though caution against underestimating them is always in order. In sorting out the prime elements of the literary forms it is more important to recognize that characters in these several literary genres and the audiences being addressed aren't expected to live peacefully for long. Anything heroic is by definition in turmoil. A holy war adds to the tumult and at the same time looks forward to something more than a temporary truce. How it is all to end varies, but some form of ultimate peace and tranquility is to follow for some. That adds conviction to the enlistment campaign and obscures such motives for aggression as plunder and contests for hegemony.

Investing personifications with human emotions makes them all the more available for intervention in state affairs. They can then single out conduits on the basis of loyalty as Yahweh does with Abraham and Moses. The Hebrew anthologists are again likely to be considered more authentic in that regard than holders of the Tablet of Destinies or the oracles of Apollo. Commandments in them were spelled out with a force and an eloquence that carry their own recommendation. The creation narrative in Genesis serves as a background demonstration of Yahweh's unparalleled strength and hence by implications the unique authority of his covenants. The power of sun and storm does something similar in the Mesopotamian, Egyptian, and classic traditions.

By making former covenants into revisionist ones, Christianity and Islam exploit the same validating power. Numerous splinter sects have since done so in their turn. Once the highest of moral grounds had been claimed, nothing less will do. The Reformation wars were a confusing crossfire of multiple sects drawing on the same sacred aura.

Milton's parody of warfare in Heaven takes a radically different turn in that respect by dissociating divine power from the call to arms. The first warrior rebel is none other than the father of lies. His heroic bluster and the passivist hero's rejection of empire in Paradise Regained are a turnaround for the poet himself, only recently a defender of the puritan rebellion and regicide. The Holy Spirit visits individuals who don't need even churches let alone armies. The Messiah in Paradise Regained thus rejects not only conventional battlefield epic but concentrations of power in any ruling elite. The link between ecclesiastical and civil hierarchies is broken. That doesn't explicitly require abandoning the Hebrew legacy, but if the rule of saints has to go it would seem to follow that the rule of ancient Jerusalem does as well. The only trustworthy expressions of divine intent and epic magnificence are the creation, the Son, and the Holy Spirit. They may lend authority to inspired poets but no longer to bishops and magistrates.

The new paradisal order, transferred off the planet, begins in the modesty of the savior, who returns unarmed and unobserved "Home to his Mother's house private" (PR 4.638-639).

\section{Incorporated Literary Kinds}

Where a narrative is as extended as those of The Aeneid and Paradise Lost, inset moments are defined by their functions in it. That includes identifiable literary forms that normally stand on their own. Their inclusion requires their redefinition, as Milton reassesses nearly every literary tradition he touches upon in putting it in a doctrinal context. Paradise Lost concerns the authorized history of the world, what started it, and what will end it. Pastoral, for instance, is thus rooted in Eden and the marriage of Adam and Eve, definitively correcting the unrequited love of idyls and eclogues and correcting the death-inArcadia theme. The original source of immorality and mortality is disobedience. Its cure is the eventual celestial paradise with no further place for classical pastoral unless in the solemn troops that move along "other streams" in "Lycidas".

All such amendments of classical traditions including dialogue, hymns, laments, and soliloquies fall under the comprehensive concept of the Light and world-making Word. Where incorporated kinds may not have had any very pronounced didactic functions on their own, in the story of man's first disobedience and divine justice they fall into place alongside everything else. 
Without exception literary forms for Milton must be defined in that context, including Hebraic ones. Indeed everything natural and human is part of a single extended narrative, cross referenced by the concept of governance as explained in the celestial dialogues. The place of different levels of word-making is defined by the allowance for free will in tension with disobedience.

Every creature is expected to keep to an assigned place in the hierarchy. Obedience means just that-making the most of one's assigned place and not leaving it. Word power comes with place. The pursuit of forbidden knowledge is equated with climbing and overreaching and thus with inflations of literary kinds, as Satan takes the Ciceronian or Senecan public speech and puffs it up into rebellion against God. After the defeat in the greatest war of all time, his real place is permanently Hell. All speeches from the rostrum and plans for conquest are puffery. What Raphael and Michael bring from outside Eden is exceptional in adding to one level knowledge from another, but then so are visitations from the Holy Spirit even now delivering the poem to the blind seer.

Why that must be so I'll consider later in the belatedness of the poet and a need for an elevated authority nearly as great as the Hebrew need for a champion above and beyond others in the Near East. In brief Eve isn't allowed to go heroic, but Milton must in the context of the post fall historical world, a prolonged interval place with a definitive beginning and ending. Put in the didactic framework of the epic, such moments gain resonance and become both models of the several literary kinds and teaching instruments. Parody, ironic scorn, and heroic bluster come with the fallen as distorted versions of proper in-place response. Hymnal celebration and contrite confession, which fall within the range of the faithful and the redeemable fallen, are unavailable to the fallen angels, who can manage only parody versions of them.

Something similar in cross referencing and partisan rhetoric is true of biblical texts as well but under various authorship and across the centuries. The cross referencing comes from backward links to former authors, as Moses in Deuteronomy is assumed as background to the prophets. The connections aren't as tight as those of a single author constructing a comparison and contrast network, but later hymns, psalms, laments, wisdom passages, and chronicles expand upon the initial Yahweh/Abraham covenant and the intervening tribulations of Israel. At any given historical moment, the disparity between the promise of the covenant and the actual situation generates much of the Hebrew anthology. The apex of the hierarchy is basically the same as that of Christianity and Islam in that in all three nothing exists that can't be connected to the omni terminology climaxed in God the Father. That is the burden of oracular sermons as well. Any segment of a population not devoted to that apex is defective. In Deuteronomy enemies who rise up before the Hebrews are to flee seven ways. Their bodies becoming "food for all birds of the air" and beasts of the earth: "I will send my fear before thee", Yahweh promises, "and will destroy all the people to whom thou shalt come... And I will send hornets before thee, which shall drive out the Hivite, the Canaanite, and the Hittite" (Exodus 23.27,28). Isaiah promises with respect to Tyre that the very earth will wither under Yahweh's assault (24.6). The Lord will heap "terror, and the pit, and the snare" on enemies (24.17) before he turns on the Israelites themselves. Do not idolize alien gods, Isaiah warns his listeners, lest "the anger of the Lord your God be kindled against you, and he destroy you from off the face of the earth" (6.14 - 15). With "curses, confusion, and frustration", he will set upon even Israelites if they have dared swerve from righteousness (28.20). If those within the fold weaken they will be smitten with blindness and confusion of mind (28.25 - 28).

In such passages Yahweh puts prior armed forces in focus as Milton's warrior Son does in finishing the war in Heaven. He has far greater power and authority than Egyptian and Mesopotamian predecessors. The listing device of the epic roll call the Hebraic texts use less to name tribes and heroes than to compile the details of mortification. Plot continuity and thematic coherence depend not only on unquestioning devotion but on genealogy. To be included in the tradition, a belated author must establish his lineage. Not all narrative episodes need emphasize that, and in fact quite a few don't, but the greater context is assumed.

Mesopotamian myth and heroic literature aren't connected in that manner. The dynasties and the divine support shift from era to era as of course do the nationalities of the authors. Some enrichment of individual texts does follow, however, from the repetition of deities even though one citation doesn't refer directly to another. Subordinate genres including incantations, petitions, rites of expiation, hymns, and laments find suitable places in individual texts without reference to an inclusive context. The connections are a matter of individual authors alluding to predecessors. Genres of devotion are nearly as prominent in Sumerian, Akkadian, Egyptian, Hittite, and Ugaritic literature as they are in the Hebrew anthology but without a direct cultural connection. That doesn't prevent them from serving city state purposes. The teaching and enlistment side of the texts is less prominent than that of oracular sermons, but it does function as the stelae commemorations of emperors testify. Any text of elevated style like any festival or ritual reinforces communal spirit. Whether readers and participants realize it or not, they are being indoctrinated. It will be collectively that they build or raze cities.

\section{Imperialism Raising Havoc}

Among warrior kings who capitalize on epic grandeur, Tiglath-pileser's memorial inscription, a mini-epic if that isn't a contradiction, claims that the gods have granted him "power and strength" and commanded him "to extend the border of their land. They placed in my hands their mighty weapons, deluge in battle. I gained control over lands, mountains, cult centers, and princes who were hostile to Ashur" (Arnold \& Beyer, 137-138). The Tiglath-pileser deities are prominent again in hunting exploits: "By command of the god Ninurta, who loves me, I killed on foot one hundred twenty lions with my wildly vigorous assault. In addition, eight hundred lions I felled from my light chariot" (Arnold \& Beyer, 142). That Ashur and Ninurta have collaborated in state expansion is the burden of the prologue addressed to them and to Enlil, Sin, Shamash, Adad, and Ishtar (137).

The last mentioned Tiglath-pileser figure, Ishtar, is the mistress of tumult as well as sex and war. Almost equally prominent in myth, epic, tragedy, and oracular sermon, Tumult, a scheme of sorts, tests the strength of heroes and upsets the protocols of civility. Though carnage is as common in Mesopotamian myth as it is in Homeric and Virgilia epic, few texts dwell on it as much as the simulated histories of the stelae commemorations. Because these are carved in stone, they don't have the magnitude of Gilgamesh and later epics, but they 
make a beginning. Conquest is the means of expanding territory, and since people defend themselves it involves carnage. In the Hebrew anthology, Yahweh is usually imagined to be the instigator, not the kings or patriarchs themselves, but the genocidal assault on Canaanite cities and killing of their men, women, and children is in the traditional pattern. If archaeological findings are correct, no actual invasion took place, and it is entirely possible that the earlier tales of conquest were also at best half true. In the invention of a heroic past to equal or exceed those of rival powers in their vicinity, Hebrew scribes, probably in the reign of Josiah, made their ancestry the equal of the Near East dynasties in conquests. Virgil does much the same for Augustan Rome in elaborating on Homer's Aeneas, son of Anchises and the goddess Aphrodite.

Less dramatically the ruckus Ezra records in the rebuilding of the temple and purging of foreign influences reduces most of the contention to lawsuits. The "people of the land" outside Jerusalem are the chief offenders. The collaborative rebuilding of the city, an unusually positive rallying of people in a hard time, draws strays back into the fold. During the exile of the Jerusalem intelligentsia, some who remained in Israel have drifted away and must be shaken up and reorganized. Within the precincts of Jerusalem, the collective psychology of cult devotion takes hold, and even on the perimeter outside the walls, cult members agree to put away their foreign wives and children and return home. The only real resemblance to epic is limited to the gathering of numbers. That is true again in the recovery effort of the families Nehemiah summons to repopulate Jerusalem.

The ultimate victory that oracular sermons project as a lasting kingdom and Milton endorses at the end of several texts is completely absent from mythology and classical epic. In the Baal cycle of Canaan, a moment's peace provides at best a hint of what could be:

Remove war from the earth,

set love in the ground,

pour peace into the heart of the earth,

rain down love on the heart of the fields.

Hasten! hurry! rush!

Run to me with your feet,

race to me with your legs;

for I have a word to tell you,

a story to recount to you:

The word of the tree and the charm of the stone,

the word that men do not know,

the earth's masses cannot understand:

the whisper of the heavens to the earth,

of the seas to the stars.

The war goddess Anat and resumed combat answer the speaker.

The oracular sermon in contrast raises the stakes both in the scope of devastation inflicted on enemies and the rewards of fidelity. It operates under a single high authority and requires a transformation of normal human psychology into a soul battle or psychomachia. After an initial concern with the former days of kings Uzziah, Jotham, Ahaz, and Hezekiah, Isaiah turns to the destruction of the Assyrians, as usual the doing of an aroused Lord. In this case he needs no assistance in inflicting "wasting sickness" and destroying the enemy's forests and fruit of the land (10.16). The devastation of Babylon will follow. As the Lord approaches "to make the earth a desolation and to destroy its sinners” (13.9), Damascus will cease to be. Egypt will look up in terror to find him riding on a swift cloud, possibly the source of the parousia phase of the New Testament's visionary end. At that terrifying sight, idols will tremble and hearts melt. The divine avenger will turn brother against brother, bring widespread confusion, dry up the Nile, and starve the people. Tyre, the Leviathan, and Ephraim will be similarly wasted.

Considerable tumult turns up in Norse, Celtic, and Germanic mythology, in the cruel deities of Central and South America, and in a milder form in the Chinese concept of the bronze age $\mathrm{Ti}$, head of an afterlife that establishes a royal court beyond turbulence. In the latter case, the carnage that brings eventual bliss doesn't take place on the battlefield but in the court itself. For a courtier's leadership to continue in a higher realm, his servants must be killed to keep him company. Herodotus' Scythians followed a similar policy. Sacrificial offerings, too, are limited carnage presented as a way to lasting peace. Invading Spain is the way to the pax Romana in the Roman historians as the conquest of Italy is the way to Augustan law and order in Virgil. It should again be clear in all these cases that any association of sadism with sanctity is a fabrication with a rhetorical purpose. It instills nationalist fervor in susceptible readers. That receives less attention than it might in anthropological accounts of sacrificial ritual, especially in the commentary of René Girard (1977) and Paul W. Kahn (2008). Prophecy, revelation, and sacred ritual are rallying devices founded on communal illusions.

It is catharsis rather than lasting peace that characterizes tragedy. If any benefits come of the protagonist's death they are shrouded in mystery. Consider Milton's Old Testament example, Samson Agonistes, and what comes to Samson's countrymen. Where prophecy and sermon look to explicit enlightenment and sometimes peace after turmoil, tragedy cuts off the endings and brings not celebration but choral lamentation:

Chorus. All is best, though we oft doubt,

What th' unsearchable dispose

Of highest wisdom brings about,

And ever best found in the close,

Oft he seems to hide his face,

But unexpectedly returns

And to his faithful Champion hath in place

Bore witness gloriously; whence Gaza mourn

And all that band them to resist

His uncontrollable intent;

His servants he with new acquist

Of true experience from this great event

With peace and consolation hath dismist,

And calm of mind, all passion spent. (1745-1758)

Unlike oracular sermons certain of their ground, in tragedy no one knows why the unsearchable works in such excruciating ways. Fate, another common theme in tragedy, takes the form of God's "uncontrollable intent.” The chorus is limited in point of view because the paradisal visions of "Lycidas" and the two epics are out of reach.

\section{The Tradition in Criticism}

Scholarship concerning early empires was handicapped until 
around the turn of the 19th-20th centuries by the lack of texts, some of which were later believed to have influenced the Hebrew anthology. Despite that shortage of evidence, Friedrich Delitzsch in the Bible/Babel movement and Hermann Gunkel's account of folklore and legend in Genesis (1903) acknowledged Assyrian literature and art to a degree not endorsed by all critics and archaeologists of their day.

That Gunkel (Kindle edition, 2011) found Hebrew literature brilliant and its amalgamation of legends "and their infilling with spirit of a higher religion" remarkable signals a shift in the evaluation of biblical texts. What counts becomes as much literary value as historical reference. Gunkel personally believed higher to be justified, but we've no way to tell whether one text encouraged its readers to be more worthy or more militant on average than another. A household with a Jewish father, Egyptian wife, and well-behaved children might be commendable, and breaking it up, as Nehemiah and Ezra urge in the reconstruction of Jerusalem, might be bad for abandoned wives and children. It remains debatable whether an especially militant text inspires barbarity or is merely picked up to rationalize a predisposition. We can estimate its rhetorical aim better than its actual effect.

Criticism of mythologies hasn't generally emphasized the social context as Gunkel and company were just learning to do. Persuasion has many uses, social and political, and neither myth nor ritual makes open use of them. As a narrative form of vague origin, it is probably better to divide myth into topics of the kind Northrop Frye and Jay Macpherson (1962, 2004) propose than to consider it a rhetorical device. The intimacy between myth and ritual also clouds the picture.

Since modern myth criticism got underway in the later 19th century, anthropologists and social critics have often assumed that myth derived from ritual. The question of priority aside, the connection is logical. Ritual is incorporated into mythic texts, and myths are reflected in ritual.

One plausible sequence would be first the personification of natural phenomena, then the development of ritual devoted to the personifications, and eventually institutionalized doctrines and codes. Whether any given culture followed that sequence is impossible to say since writing came several thousand years after the first settlements. It does appear, however, that personifying natural phenomena led to the establishing of shrines and of rituals addressed to gods and goddesses. An unrecorded sun myth could have resulted relatively quickly in the Mesopotamian Shamash or the Egyptian Re, or it could have taken centuries. The only social effect we need to acknowledge at the moment is that whatever induces people to think alike promotes coordination.

In The Hero: A Study in Tradition, Myth, and Drama (1956), Lord Raglan (1990) championed the anteriority of ritual, albeit acknowledging a shortage of proof. With Carl Jung, Mircea Eliade, Ernest Cassirer (1946), and Joseph Campbell, psychological and archetypal studies and some philosophical ones complemented myth/ritual ones. Ritual has some of the stageby-stage movement of mythic narrative but lacks the characters in conflict who populate story-form myths of origin. Its main purpose seems to be to create a sense of belonging through participation in solemn ceremony. Where antagonists appear in ritual they are defeated abstractly and without tension of the kind that accompanies epic upheaval. In any case, both myth and ritual must have coexisted long before Sumerian and Akkadian scribes recorded them. Gilgamesh, The Epic of Creation,
Erra and Ishum, Atrahasis, Babyloniaka, and the Baal cycle of Canaan include ritualized passages. Even their battles are closer to ritual demonstrations than the nationalist wars of the Deuteronomist or the carnage of Homer, Virgil, Statius, and Lucan. In imagining gods stirring up seas, raising floods and storms, destroying crops, burning forests, and inflicting famines and plagues, myths assign them both cyclonic power and regularity, much as nature itself mixes springtime growth, crops, irregular floods, and storms.

\section{Inspiration and Belatedness}

Conduits, vessels, and messengers transmit influence from one imagined level to another.

That is true alike in myth, epic, and oracle. What are actually conveyed, however, aren't messages from elsewhere but literary conventions, and they come from prior poets. The later prophets harken not directly to Yahweh but to precursors. Virgil (1990), Lucan, and Statius (2004) wouldn't have known about Homer's anonymous predecessors, but they acknowledged Homer himself.

Their belatedness affects the stance they assume in announcing the themes of their texts. Virgil's "Arma virumque cano" ("I sing of arms and the man") is Latin voicing in response to Homer. In the Song of Roland, in Dante, Malory, Spenser, and Milton, arriving on the scene late presents a more involved heritage. Dante's making Statius an honorary Christian parallels his use of Virgil as a guide through the Inferno.

That particular selection of sources may have been due to The Aeneid and The Thebaid framing ethical issues in terms of individual merit and to the exegetical practice of turning classics into anticipations of gospel. Even so, Statius seems an odd choice, since it is the fate of the polity rather than individual warriors to which the bird flocks of Melampus and Amphiaraus (3.500 - 548) refer. A reluctant city that takes no joy in warfare has no "fire or spirit" (4.345 - 355). Another reason for Dante's choice, however, may have been simply to underscore the limitations of classical authors. If so that is a typical betterment of sources, which is often the claim of the belated poet, as a new testament if more enlightened than an older one. Dante's Latin sources can go only so far in the progress from the Inferno to Paradise before someone equipped with revealed knowledge takes over. The angelic host is ranked around a mystic center in a state of peace and in visionary splendor beyond classical and Hebraic literature. The choral configuration is unlike anything in the epic battlefield hosts except in numbers and elevated style. As an even more belated poet, Milton too displaces classical epic and English versions of the heroic situated in monarchical and courtly settings as they are in Malory, Spenser, and Shakespeare's battlefield plays. Converting the traditional muse into the Holy Spirit enables the poet to transcend courtly patronage and its compromised literary environment. Expecting to become a conduit of the sublime equal to biblical precedents isn't necessarily egomaniacal, since in De Doctrina Christiana inspiration is required merely to read scripture. In "At a Solemn Music," "Il Penseroso," and Paradise Regained the conclusion is cast in choral amplitude similar to that of "Lycidas" (as a Roman Catholic poet, Dante isn't in the picture), where those who dwell with God “weep no more," as in Isaiah (30.19). That departs less decisively from militant Hebraic prophecy than one might expect, because once the purge is completed in Isaiah not only will Egypt, Tyre, Assyria, and Babylon have ceased to be 
but the wolf will dwell with the lamb and the cow and bear feed together (11.6 - 9).

Where belatedness brings a power to lift the poet to the level of his predecessors or beyond, the reception involves considerably more than merely a decision to write a long poem. Should the vessel be pulled abruptly out of his or her life, the reception can become traumatic if not fatal. The bard of Paradise Lost isn't subject to that trauma, perhaps because his blindness and the failure of the Puritan rebellion have already cast him out on his own:

So much the rather thou Celestial Light

Shine inward, and the mind through all her powers

Irradiate, there plant eyes, that I may see and tell

Of things invisible to mortal sight. (3.51 - 55)

Through all her powers is crucial, however. If the poet is to elaborate on scripture, the mind must be cured of deficiencies. Knowledge of divine dialogues, the creation, and Satan's counterplot would otherwise be forbidden. Where the deities of Homer and Virgil determine battles and national destinies, Milton's version of the trinity is responsible for the entire universe. What is revealed to the poet can include events that occurred before mankind even existed.

Even in the classical tradition where revelations are less inclusive some who are chosen as vessels can't take them in as easily as the prophets and Milton do. In the extravagant fifth book of Lucan's Civil War (1992), a divine vision brings extreme trepidation despite its recipient having observed the appropriate ritual. Wanting to know his future and thinking to forward Fate, Lucan's Appius visits the caves of Phoebus and forces Phemonoe ("prophetic mind") to make herself receptive to Apollo- to be "received in virgin's breast... as the Sicilian peak gushes when Etna/is pressured by the flames” (5.97 - 99). Knowing the danger of becoming such a vessel, Phemonoe refuses at first. When Appius insists, she is driven out of her mind and runs wild through the cave "dislodging with her bristling hair the headbands of the god/and Phoebus' garlands”. Only in madness can an ordinary mortal receive such an extraordinary vision:

\section{All time converges into \\ a single heap and all the centuries oppress her unhappy breast, \\ the chain of happenings so lengthy is revealed and all the \\ future \\ struggles to the light and the Fates grapple \\ as they seek a voice; everything is there: the first day, the end}

of the world, the Ocean's size, the number of the sand.

(5.178 - 182)

Any mind would have to strain beyond its limits to number the sands and foresee events to the end of the world. Some vessels responsible for visions of such magnitude are struck dead outright, "Because, if the god enters any breast, an early death is the penalty... the human framework falls apart under frenzy's goad and surge, and the beatings of the gods shake their brittle lives” (5.116 - 120). Even as Lucan distinguishes between inspired godliness and madness, his epic benefits in scope and intensity from Phemonoe's fury, a variant of the tumult/mystery complex.

Where the gods descend, amazing things happen, good and bad. Whatever else happens, the text gains in broadcast volume.
A delivery from beyond calls for some such amplified voicing, which translates as we've been seeing into rhetorical authority. Milton's narrator calls out warnings as if to mankind in general. Lucan grows melodramatic. That turbulence is only to be expected where a new order must destroy an old one. If the message isn't convincingly delivered, the prophet fails in his calling.

History has many an unheeded prophet considered to be mad or fraudulent. Some who were eventually accepted by a cult were initially doubted on the street, as Mohammed was in Mecca.

Determining which annunciations and which texts are authentic has an all-or-nothing polarity about it. Not to be chosen is to be cast into outer darkness or taken as an anti-Christ, or what amounts to almost the same, being excluded from the canon and left unread. Apocrypha have nowhere near the standing of canonized literature, and because of their truth claims they have turned away from the category poesis from the outset.

\section{Disbelief}

One needn't be too deferential about assuming that skeptics lived side by side with ardent believers even where they left no texts. It is doubtful that all readers of stelae credited everything they said. That doesn't raise any problem with a Statius or Virgil, but it does with the core texts of some cultures. At least some of the time in their original settings as now hyperbole would have been recognized for what it is. Bruce G. Trigger (2003) cites newly conquered tribes among the Incas who remembered that before they were ruled by the sacred Inca king "their world had functioned perfectly well without him" (250). No evidence exists "that subject groups anywhere accept theocratic claims uncritically and much evidence that they generate their own counterideologies”. Going against the grain can carry a stigma, as whistle blowing still does, but that is by no means universal: "If fear of divine sanctions alone were an effective control," Trigger continues, "why did all ancient states have to guard temples, palaces, and government storehouses from thieves and threaten robbers with drastic physical punishments?” (250).

In reading biblical literature, modern critics like Robert Alter, Harold Bloom, Kenneth Burke, Herbert Schneidau, Meir Sternberg, Gerald Bruns, Frye in several works (1962, 1982, 1990), and Harold Fisch have taught us a good deal about poetics but typically less about the circumstances of composition, contemporary agendas, and dissent. Archaeologists, historians, and some textual critics have done better in that respect. The militancy of oracular texts would have little purpose unless their authors considered disbelief to be abroad. Condemnation of the unholy is what gives them their edge. The Hebrews found abominations among and all around them. The frequent Muslim practice was and still is to consider non cult members infidels. The medieval Christian practice was to portray them as monsters. As Michelangelo's fantasy painting of Saint Anthony's torments illustrates, saints and martyrs were vulnerable to their bestial attacks. That is closer to traditional myth than to epic.

Where codified doctrine, laws, and ordinances enforce orthodoxy, dissent is more likely to arise. It no doubt occurred to some under Hammurabi's Code to question whether the gods really wanted the hands cut off a child that struck its father. Or 
wanted the daughter of a man who had fatally struck an upper class woman to be executed in the man's place (Arnold \& Beyer, 113). As the stridency of the sermons suggests, the militancy of the Hebrew prophets was even more prone to raising dissent. It can crop up anywhere, however, within an ecclesiastical order, in palace revolutions, and in families. From the beginning of Israelite kings, Saul and Samuel as representatives of civil and religious orders were at odds. Saul didn't take Yahweh's instructions literally enough, and divine commandments allow no margin of error: "Now go and smite Amalek and utterly destroy all that they have, and spare them not; but slay both man and woman, infant and suckling, ox and sheep, camel and ass" (15.3). In the opinion of Samuel, Saul is soft on idolatry.

Samuel's berating of him (1 Samuel) for sparing King Agag is clear about what must be done to reconnect the current kingship with the legacy of Abraham and Moses. As a priest he carries out the duty Saul has shirked: "And Samuel hewed Agag in pieces before the Lord in Gilgal” (15.33). Before the Lord is the key: to be sanctified, any act must conform to divine mandates where they exist.

Whatever the level of dissent among contemporaries, it is likely to be greater outside the culture where little that claims to be inspired is genuine and much spurious. That goes as much for those who write of Enlil, Marduk, and Baal as it does for Lucan writing of Phemonoe and Apollo or for Milton writing of things invisible to mortal sight. It is Homer who assigns the plot-forwarding roles to Poseidon, siding with the Greeks, and Zeus, siding with the Trojans. He it is alone who assigns plotting and strategy to Zeus and Hera and field operations to Poseidon and Apollo. At the outset of The Iliad the narrator announces his subject in what becomes a conventional announcement of any epic subject of magnitude:

Sing, goddess, the anger of Peleus' son Achilleus and its devastation, which puts pains thousandfold upon the Achaians,

hurled in their multitudes to the house of Hades strong souls

of heroes, but gave their bodies to be the delicate feasting of dogs, of all birds, and the will of Zeus was accomplished

since that time when first there stood in division of con-

flict

Atreus' son the lord of men and brilliant Achilleus. (1.1 - 7)

Despite bodies eaten by dogs and birds and souls hurled into Hades, putting gods in the picture raises havoc to a high level. In the death of heroes, tragedy and epic would converge but for epic's panoramic scope. Without the horrors, the combat would be less intense and heroes less heroic, as tragic plots would be less cathartic if pity and fear were diluted. The psychology of sacrificial offerings calls for that expenditure of emotion on the way to exhausted rest.

\section{A Suitable Antagonist}

Least filled with what might be taken for realism are ogre tales and parables, the episodes of which can be vivid without much detail. In the manner of gargoyles and caricatures, belittling tales are sometimes directed at specific groups or classes, as in the portrayal of owners and overseers from the standpoint of slaves and laborers or of the morally depraved as seen by the righteous. Collecting ogre-like deformity into a single archetype produces a generalized scapegoat responsible for the world's failings. Scapegoats need have no particular assigned character or single origin. The child-killing monster-goddess Lilith is quite different from misshapen ogres, more like the deadly beautiful witches of fairy tales. In the context of supreme fictions, the more powerful the deity, the more comprehensive the trouble maker has to be, unless, as in Spinosa, tribulations are inflicted by God himself to strengthen character, an odd way to explain an infant dying of the whooping cough. During early Christian recruitment when the synoptic gospels were being written, the apostles demonized rival cults including Judaism and admonished converts to abandon what from then on must be regarded as heresy.

Elaine Pagels in The Origin of Satan (1996) charts the best known of the personified evils, Satan (al-Chadian in Arabic and Islamic tradition), following him through several incarnations ranging from an early Jewish superhuman to the author of all evil in Dante and Milton. In Numbers and Job, Satan is the virtual agent of the Lord himself, in other versions both an adversary and a collaborator. In Milton at the precise moment God makes the Son the highest communicant and the soon-tobe voice that brings the cosmos out of chaos, he springs into being as confusion personified. The negative element the Word lacks he must provide if the linguistic spectrum is to be filled out. The cannons he invents not only parody epic but put communication in Belial's punning "terms of weight". The cannon's mouth opens and chaos rather than a proclamation belches out. Rather than dance out choral responses the good angels tumble in disarray.

Polytheistic monsters serve similar purposes in Greek myth, but the furies and harpies among them tend to be regional and aren't associated with national enemies. They are thus more avoidable than the universal Satan, though an angry Minerva or a Juno (in The Iliad and The Aeneid respectively) is far ranging. If Troy is to burn or if Turnus is to wage a senseless war he is doomed to lose, the reason is to be sought in bickering immortals. It is unclear finally whether they or Achilles and Aeneas determine the outcome, but from the viewpoint of literary criticism it doesn't matter: both serve as story-extending complications and occasions to display courage, loyalty, and betrayal.

In distinguishing one thing from others, language defines by exclusions and opposites. Ceci n'est pas un pipe, the Magritte painting of a pipe declares. Neither is the word pipe a pipe. True and false come as inextricably entwined as accurate and inaccurate, integrate and disintegrate, construct and deconstruct, good and evil. In mythic terms, an archetypal contrarian or anti-Word comes before specifically detailed negatives. The heroic raises the specter of mock heroic. In Milton only when the opposite of the Word has been ushered in can language include sarcasm, scorn, baiting, name calling, strutting, posturing, feigning, hoaxes, fraud, falsehood, tall tales, simulation, mendacity, skullduggery, pretense, feigning, diddling (even taradiddling), swindling, rooking, toying with, forging, foxing, and fobbing. Multiplying that English vocabulary by thousands of equivalents in other languages gives us some idea how inventive Homo ludens-deviosus-insidiosus-homicidus has been for possibly some 2000 word-wise generations.

\section{REFERENCES}

Arnold, B. T., \& Beyer, B. E. (Eds.) (2008). Readings from the Ancient 


\section{H. TOLIVER}

Near East. Grand Rapids, MI: Baker Publishing Group.

Cassirer, E. (1946). Language and Myth. New York: Dover.

Frye, N., \& Macpherson, J. (1962, 2004). Biblical and Classical Myths: The Mythological Framework of Western Culture. Toronto: University of Toronto Press.

Frye, N. (1982). The Great Code: The bible and Literature. New York: Harcourt Brace Jovanovich.

Frye, N. (1990). Words with Power. New York: Harcourt Brace Jovanovich.

Gilgamesh (1991). The Epic of Gilgamesh (A. George trans.). London: Penguin.

Gilovich, T. (1991). How We Know What Isn't So: The Fallibility of Human Reason in Everyday Life. New York: Simon Schuster.

Girard, R. (1977). Violence and the Sacred (P. Gregory trans.). Baltimore: Johns Hopkins University Press.

Gunkel, H. (2011). Israel and Babylon: The Influence of Babylon on the Religion of Israel. Kindle edition.

Herodotus (1972). The Histories (A. De Sélincourt trans.). New York: Penguin.

Hesiod (2004). Theogony, Works and Days, and Shield (A. N. Atha- nassakis trans.). Baltimore: Johns Hopkins University Press.

Kahn, P. W. (2008). Sacred Violence: Torture, Terror, and Sovereignty. Ann Arbor: University of Michigan Press.

Lucan (1992). Civil War (S. H. Braund trans.). Oxford: Oxford University Press.

Milton, J. (1957). Complete Poems and Major Prose (M. Y. Hughes ed.). New York: Odyssey Press.

Pagels, E. (1995). The Origin of Satan. New York: Random House.

Raglan, L. (1990). The Hero: A Study in Tradition, Myth, and Drama part III (1956) in In Quest of the Hero. Princeton: Princeton University Press.

Shermer, M. (2011). The Believing Brain. New York: Henry Holt and Company.

Statius, P. P. (2004). The Thebaid: Seven against Thebes (C. S. Ross, trans.). Baltimore: Johns Hopkins University Press.

Trigger, B. G. (2003). Understand Early Civilizations. Cambridge: Cambridge University Press.

Virgil (1990). The Aeneid (R. Fitzgerald trans.). New York: Random House. 